\title{
PSYCHE.
}

\section{BIOLOGICAL AND OTHER NOTES ON AMERICAN ACRIDIIDAE.}

BY SAMUEL H. SCUDDER, CAMBRIDGE, MASS.

Tettix granulatus Kirby. This species flies in arches from six to ten feet in length and a foot in height at the most, without swerving to one side or the other.

Chloealtis conspersa Harr. The eggs have a slight curve, so that when the embryo is formed it lies with the head downward and the back slightly bent. The surface of the egg is microscopically reticulate, the cells of the reticulation $0.035 \mathrm{~mm}$. in diameter with raised walls between them. During the winter the embryo is in a stage of development apparently equivalent to the second or third stage of Diplax as given by Packard; the labium is unmistakably grouped with the legs and nearly as long as they; it is not until spring that the abdominal segments are mapped out, at least upon the dorsal and ventral surfaces. The eggs are excluded cap foremost, and in different pods counted were IO, I I, I4, IO, 4, 6, 6 .

In the Geology of New Hampshire I gave some account of my observations on this insect at Sudbury, Vt. Subsequently I elsewhere observed that the number of notes of the male in stridulation varied from seven to sixteen and that in the sun the rate at which they were produced was nearly four per second.

At West Campton, N. H., June 3, I found in one egg-cluster the empty puparium of a Tachinid fly, and in another cluster, on removing the cap, the pupa of Trichodes nuttalli which yielded the beetle June 23d. Dr. LeConte determined the beetle and wrote at the time that " $T$. alvearius of Europe lives in the larval form in nests of mud wasps and $T$. apiarius of Europe in bee hives"; in still another cluster I found a coleopterous larva, never determined, between the eggs and the cap; it was fat and plump, although the eggs were untouched.

Stenobothrus curtipennis (Harr.). I have timed the stridulation of this species many times with somewhat varying results. I noted first, what I have already published, that " the notes are produced at the rate of about six a second and are continued from one and a half to two and a half seconds," but that they were less rapid when the sky was overcast. These were from observations at Hampton, N. H. At Jefferson, N. H., on a warm and sunny afternoon, I observed that the rate was 
nine per second and the duration as before, but the observation was not a very extended one. Later, at the same place I took more careful observation, and have noted it as certainly correct, that the duration was as before and the rate ninety-four in fifteen seconds. As in Chloealtis conspersa the first one or two strokes are frequently noiseless, the femora apparently failing to strike the tegmina; and when they are struck the notes are shorter than the succeeding. At Sudbury, Vt., this species occurred almost exclusively in the uplands, rarely in the low meadows.

The ovaries are very large and thick, pale pinkish at base, pale or colorless apically; the eggs appear to be arranged upon them like the bristles of a brush, having their free tips turned toward the middle line of the body; the larger eggs are beneath and the upper portions of the ovaries are attached together quite strongly by a delicate tissue. The eggs of opposite sides touch by their tips, are pale yellowish and appear to be in three, possibly four, tiers. Of several females dissected August I5, I counted in one 39 eggs on one side, 30 on the other; in another 45 and $4^{2}$ respectively; in a third, $3^{8}$ on each side. Still another had no eggs at all, but instead the entire abdominal cavity was crowded with the coils of a Filarian worm, which when removed measured nearly two feet in length.

Encoptolophus sordidus (Burm.). The imago first appeared at Sudbury, Vt., on Aug. I5, in 1868 , the specimens still pale from freshness. In Cam. bridge, Mass., Oct. Io, r867, the males were very abundant, but not a single female was noticed.

The eggs are extruded cap-end foremost, and laid in a mass in drilled holes in bare spots in sandy compact loam, so deep that the top of the pod is about two centimeters below the level of the ground. Late in the afternoon of September 30, at Andover, Mass., I noticed a female which had just completed her task standing within her own length of her filled-up hole, the whereabouts of which was revealed by the scratched appearance of the soil, completely exhausted; her ovipositor was hoary with froth and she made no attempt to escape. She had evidently further eggs to lay. A second open hole only a few centimeters away had no eggs, but near the bottom an elaterid larva was discovered which probably led to the abandonment of the hole.

Camnula pellucida Scudd. July 22, I 867, this species appeared in very great numbers at Jefferson, N. H., the males more abundant than the females. It was the first pleasant day after four days of storm, just before which the fields where these occurred showed no mature specimens at all.

Dissosteira carolina (Linn.). The eggs are laid in a mass as in Melanoplus, only the pod is larger. In one found in Springfield, Mass., laid in damp soil, there were about forty eggs, which were laid not horizontally but with a slight obliquity, and the diameter of the pod was about half as long again as one of the eggs. In a pod formed 
on the side of a knoll, where the earth had afterwards fallen away, partially exposing the eggs, each exposed egg had been pierced by a parasite, Scelis ovivorus Riley, which emerged Sept. I8, one from each egg and about a dozen in all.

A male and a female taken in coitu at Niagara Falls, Aug. I8, were preserved and from the body of the female there issued early in September two Tachinae which Mr. C. H. Tyler Townsend has identified for me as Sarcophaga oedipodinis Towns. Ms.

An embryo $7 \mathrm{~mm}$. long and nearly formed was observed some years ago. As viewed from above the prothorax is no larger than the other thoracic segments and these are entirely similar to the abdominal, no regional distinction being perceptible. The hind femora are long and reach the end of the third abdominal segment ; the tibiae are bent at right angles toward and across each other, the tarsi curving backward, outward, and upward. The middle legs are not alike. On one side, the femur lies upon the base of the hind femur and the tibia and tarsi bend sharply back upon the femur and parallel to it; on the other, the femur lies entirely within the hind femur (i.e., toward the middle line of ventral surface of body) and the tibia bends at first at slightly less than a right angle to it, then is twisted, and the tarsi are finally directed toward a point between the insertion of the middle and hind legs of the opposite side, and the extremity apparently between its opposite neighbors. The fore femora run in the same direction as and parallel to the hind femora and the tibiae and tarsi are bent sharply back upon the femora but run a little beneath both them and the tibiae of the opposite pair, so as to be only partially visible.

The labrum, strongly bilobed at apex is bent downward and appressed against the face, the two mandibles (the black denticles at tip being formed) being separated from each other by the labrum, their insertions being nearly or quite as far apart as those of the forelegs. The maxillae seem to arise in the middle line beside and partially concealed by the mandibles, directed outward, and one of them twice as long as the other; the two halves of the labrum arise in a similar way, but lie beneath the mandibles. The antennae come down in front of the eyes, being pushed toward them by the protuberant mandibles; one of them is broken, nothing but the stump being visible! Just behind the base of the hind femora, in the place of the body of doubtful character in Rathke's figure of the embryo of Gryllotalpa, is a shining lenticular elevation.

In 1865 the imago first appeared on June 29. On Oct. Io, I867, the species were by no means uncommon in Cambridge, but I could find only females, and the late Mr. Sanborn told me that the same was true on the same day at Andover, Mass.

Mr. J. A. Allen tells me that in Iowa the species occurs only by roadsides and in rather dry places. A specimen flew into the window of the late Professor 
Baird's house in Washington, D. C., on the night of July I9, I868.

Dictyophorus reticulatus Thunb. A specimen kept in captivity was excessively deliberate in its movements; to clean its antennae it treads upon one at a time and draws it from under its feet; it was very tame and would leap but a few inches at a time. Two specimens from Lookout Mt., Tenn., were sent me by Mr. B. P. Mann, both females, and when received (by mail) one had eaten the entire abdomen of the other excepting the sternal portions and the ovipositor; yet the injured specimen did not seem to mind it greatly!

Melanoplus femur-rubrum (De Geer). At Sudbury, Vt., specimens taken in low meadows differed from those captured in hollows of dry upland hilly pastures in being darker colored and having more contrasted coloration. Three quarters of an hour after sunset on a cloudy evening in August a specimen was unable to see my hand, as it several times did not move until touched; then, however, it jumped to another blade of grass. The experiment was tried several times with the same individual and with the same result.

Melanoplus collinus Scudd. This species was found abundantly at Sudbury, Vt., where, on Aug. 15, no eggs could be found in the ovaries of the females examined; the ovaries were spread as a mere film on the intestines and no eggs could be detected with a strong pocket lens.

Melanoplus femoratus (Burm.). The ovaries in this species occupy the dorsum of the body from the metathorax to the fifth abdominal segment inclusive ; at the latter point the oviducts turn ventrad, clasping the alimentary canal, meeting beneath and turning backward together to the ovipositor; the tracheae pass between the ovaries and the intestine and branch upon the former.

\section{A RARE TRACT.}

There has lately. been presented to the library of the American Entomological Society by Mr. Wm. J. Fox, a small pamphlet $\left(3 \frac{1}{2} \times 5 \frac{1}{4}\right)$ from the library of the late T. R. Peale, which bears the title: "Catalogue of the Lepidoptera of New Orleans and its vicinity, prepared by $\mathrm{L}$. von Reizenstein. Printed for R. C. Kerr, librarian of the New Orleans Academy of Sciences, New Orleans I863." There are some items of interest in the catalogue to which attention may be called. 'The following species are credited to the district mentioned.

"Papilio protesilaus Dru. Greenville, rare." This is given by Kirby as a synonym of Sinon Fabr.
"Goniopteryx eclipsis" = Gonepteryx maerula Fabr.

" Xanthidia (Terias) sylvatica Mss. rare, Western Lake Shore."

"Heliconia diaphona" =Ithomia diaphanus Dru. Dr. Scudder says of this species (Syn. List; Buff. Bull. 2, 246, I875): “I cannot find any authority for the occurrence of this butterfly within our limits, excepting Edwards, Synopsis, and Mr. Edwards does not recollect upon what grounds he placed it there."

"Argynnis briarea Godt rare." "Leminitis? cadmus Cram.? pherecides Cram:" These last two are synonyms of Aganisthos acheronta Fabr.

"Apatura myops Mss. on elm trees." 

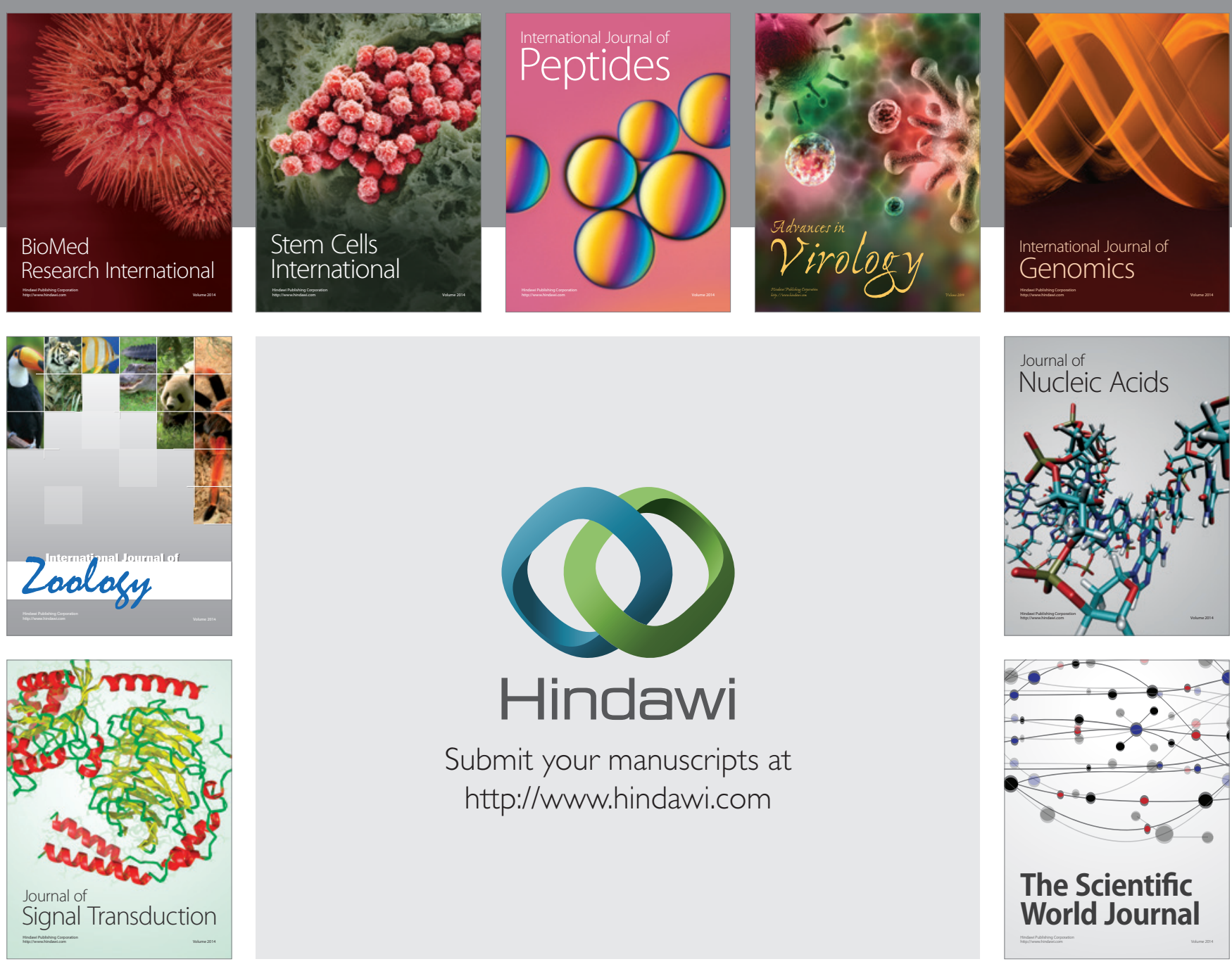

Submit your manuscripts at

http://www.hindawi.com
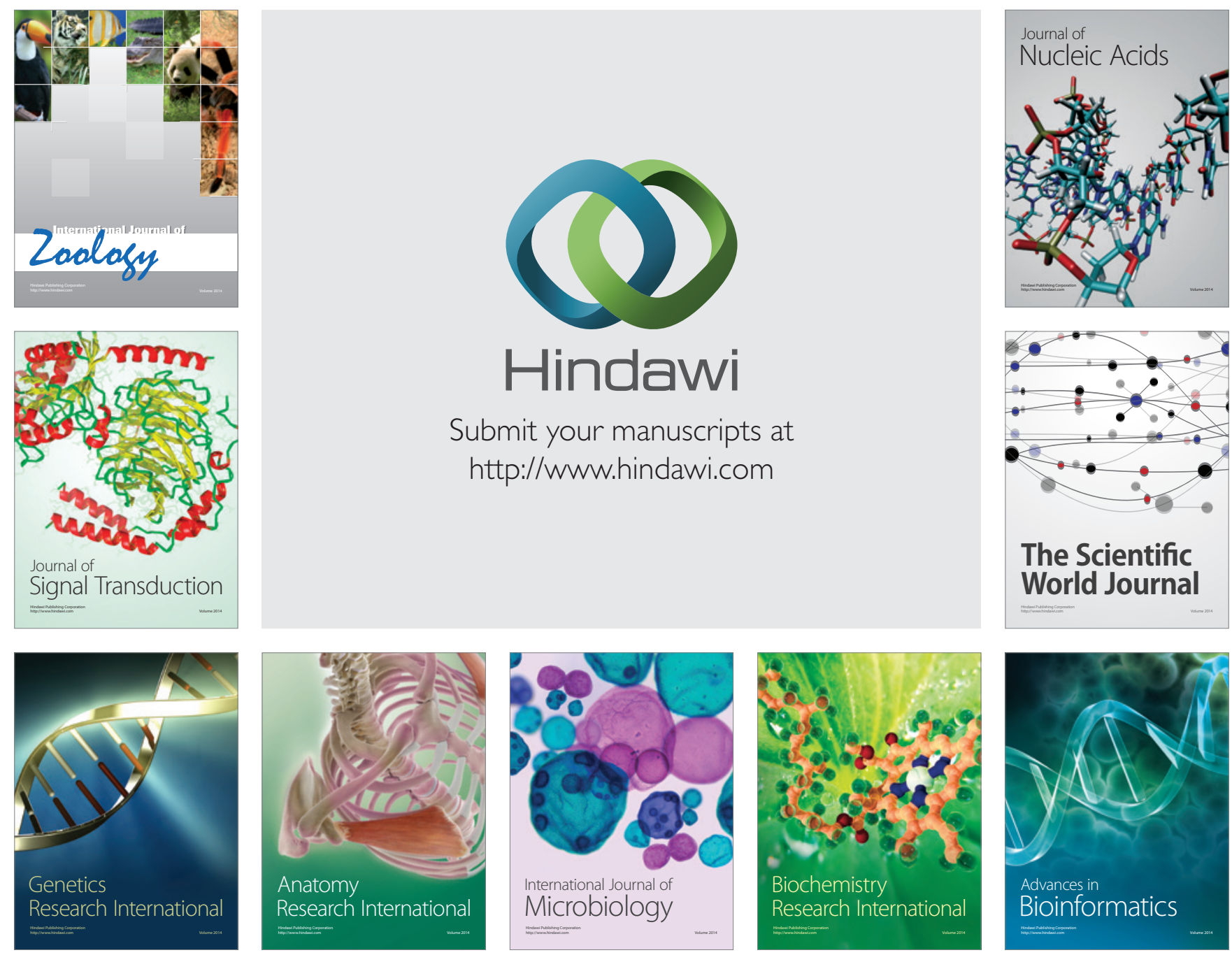

The Scientific World Journal
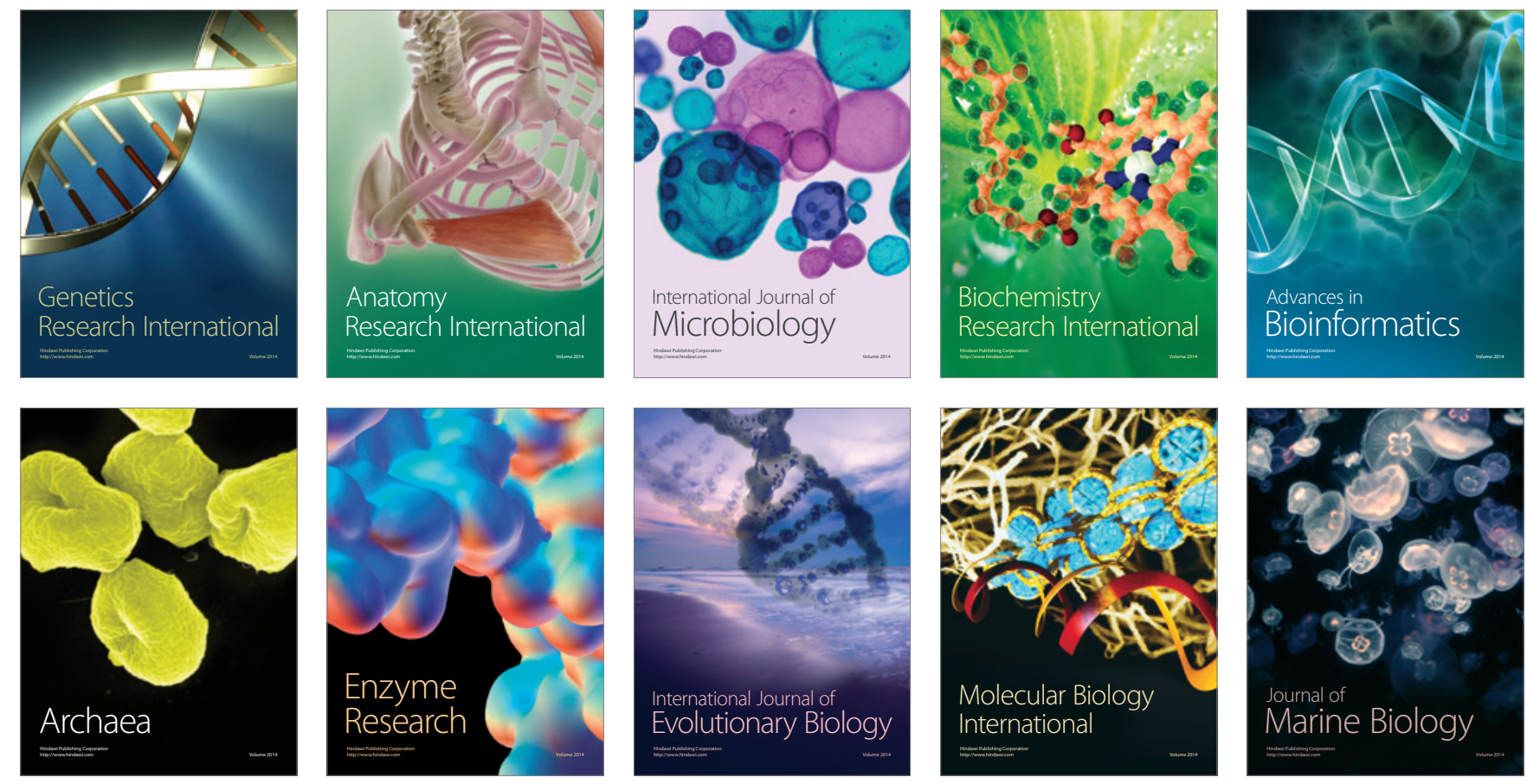